\title{
The Future of Rain-Fed Horticultural Crops Production in a Changing West African Climate
}

\author{
Chinedu Felix Amuji ${ }^{1,2 *}$ \\ ${ }^{1}$ Department of Biological Sciences, Faculty of Science and Engineering, Macquarie University, North Ryde \\ NSW, 2109, Australia \\ ${ }^{2}$ Department of Crop Science, Faculty of Agriculture, University of Nigeria, Nsukka 41001, Enugu State, Nigeria
}

\begin{abstract}
In West Africa (WA), there are high rates of poverty, population growth rate and food insecurity, and most agricultural productions are conducted at mostly an un-mechanized level, with almost a complete reliance on rain-fed conditions. This review provides an overview of climate change across WA and its impacts on key horticultural crop groups (vegetables, plantations, fruits, roots and tubers). The review also identifies areas within WA where these crops may be more or less vulnerable to changing climatic conditions. Empirical studies using climate change models were synthesized and analyzed for reliable future climate projection effects on the production of region horticultural crops. The two climatic variables likely to have the greatest effects on the horticultural crops in the region are temperature and precipitation, with the latter considered to be of superior influence. As climate change continues to intensify with time, so does its impact on rain-fed horticulture. The study showed that the Sahel areas of the region would be the most affected and that horticulture production in that part would be significantly impacted. The study found that the impact of climate change on the WA region is not uniform across the different ecosystems. Therefore, its effects on horticultural crops will also differ across the region: in some areas, the crop yields would increase, while in others it might decrease depending on the type of plant and the ecology being considered. This creates an urgent need to understand and synthesize the responses of horticultural crops to climate change and identify adaptation options. Adaptation actions and strategies are all discussed, education, the introduction of new cultivars, the development of effective cropping systems, the transference of skills from other regions, and the expansion of farmer-government-NGO collaborations.
\end{abstract}

\section{Keywords}

climate change, food security, horticulture, rain-fed conditions, West Africa

\section{Introduction}

Climate change is predicted to affect the entire planet [1,2], given that future climatic changes will impact natural ecosystems and those areas modified by humans [3]. West Africa (WA) is recognized as one of the region's most vulnerable to anthropogenic climate change [4,5,6] due both to its geographical position [7] and socioeconomic factors such as rapid population growth and relatively low levels of industrialization [8]. In addition, WA has experienced an increase in mean annual maximum and mean annual minimum temperatures $\left(0.16^{\circ} \mathrm{C} / \mathrm{decade}\right.$ and $0.28{ }^{\circ} \mathrm{C} /$ decade respectively) over the last 50 years, as well as more frequent heatwaves and declines in the number of cold days [9]. In some areas within the region, annual precipitation has fallen to $20-40 \%$ compared to the levels in the 1970s. In addition, there have been substantial deviations in monsoonal precipitation, along with increases in storm and flooding events across tropical and coastal zones, with prolonged and frequent drought within arid zones [10]. 
Continental WA $\left(5^{\circ} \mathrm{N}-35^{\circ} \mathrm{N}\right.$, and $15^{\circ} \mathrm{E}-15^{\circ} \mathrm{W}$; Figure 1) is composed of 14 countries: Benin, Burkina Faso, Gambia, Ghana, Guinea, Guinea-Bissau, Ivory Coast (Cote d'Ivoire), Liberia, Mali, Niger, Nigeria, Senegal, Sierra Leone, and Togo. Bounded in the north by the Sahara Desert and in the south by the Atlantic Ocean, this region is home to about $30 \%$ of Africa's population and $5 \%$ of the world's population [11]. In recent decades, WA has experienced high population growth ranging from 2.7 to $3.0 \%$ per annum (p.a.) [12] and is expected to reach 490 million people by 2030[13]. However, the human population and natural resources are distributed unevenly throughout the region.

Agriculture throughout WA is influenced by a number of factors, such as geographical location, the people involved and their socio-economic backgrounds, interactions between people and the environment, and the evolution of biodiversity. Agriculture is a primary and fundamental component of the economies of most countries of the region, contributing up to 35\% of their total Gross Domestic Product (GDP) [13] and providing employment for $65 \%$ of the population [14]. Currently, more than $70 \%$ of all agricultural production activities are conducted at an un-mechanized level, with little to no irrigation facilities $[15,16]$. As such, advances in agricultural production have been limited, leading to flow-on problems associated with food productivity and security, which are often identified as a major cause of insurgence uprising [17]. Yet, agriculture remains a low priority among the policies of individual national governments for eradication of poverty, economic diversification, empowerment and security, environmental sustainability and management [15]. For example, public spending on agriculture in Nigeria measured by the percentage of agricultural expenditure in agricultural GDP is amongst the lowest in the world [18].

Horticulture constitutes a major sector in plant agriculture [19] and plays a key role in the generation of personal income, foreign exchange earnings, the provision of employment, and food security. Major horticultural crops from WA for consumption and export include tomato (Solanum lycopersicum), potato (Ipomoea batatas), and onion (Allium cepa), as well as a growing trade in cassava products and yam [20]. Presently, as with other forms of agriculture in this region, the moisture requirements of these crops are met primarily through precipitation rather than irrigation. However, climate change is highly likely to impact rain-fed cultivation. Hence, climate change has the potential to be a substantial disruptive influence on some of the poorest and most politically insecure countries in the world [21].

Climatic variables play a significant role in determining the establishment and growth of horticultural crops [22]. However, to date, no work has specifically linked the climate change effect on horticultural crops production under natural rain-fed conditions in WA. In this work, the current state of knowledge of the potential impacts of climate change on rain-fed horticultural crops in WA was considered. Also, the likely scenarios of future climate change that might affect the region in the near future were examined, and the responses of key horticultural crops to recent climate change and the projections of future changes of crop yields and habitat suitability were identified together with the adaptation strategies and initiatives that may aid policy development and promote food security at national and regional levels.

To achieve the above-mentioned objectives, the following steps were followed: (i) a review of the current state of knowledge of the potential impacts of climate change on rain-fed horticultural crops in WA; (ii) a consideration of the likely scenarios of future climate change that might affect the region over in coming decades, the responses of key horticultural crops to recent climate change, and the projections of future changes to crop yields and habitat suitability; (iii) an identification of the adaptation strategies and initiatives that may aid policy development and promote food security at national and regional levels. 


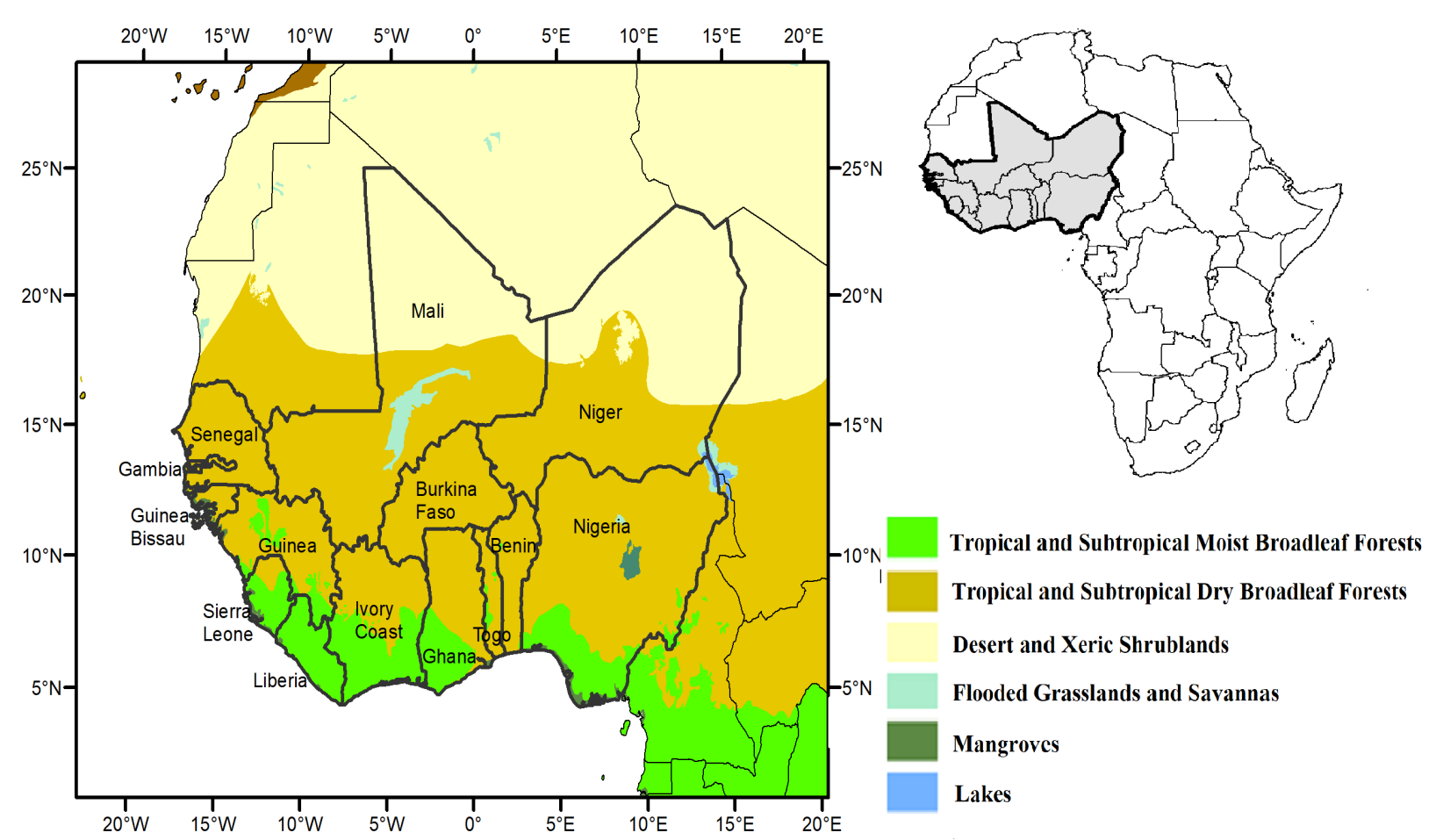

Figure 1: Countries of West Africa with major biomes

\section{Discussion}

\subsection{Observed and projected climatic trends}

The climate of WA is strongly influenced by the West African Monsoon [7], in addition to temperature and precipitation being controlled by the global ocean and air temperatures [23]. The region is defined by four distinct eco-zones running west to east across the continent. In the south and bordering the Atlantic Ocean lies the Guinean and Guineo-Congo eco-zones. These two zones contain belts of the tropical forest [24] (Fig.1) and are characterized by high precipitation and humidity. While the wettest areas may have precipitation exceeding $2000 \mathrm{~mm}$ p.a. [25,16], this gradually decreases with increasing latitude. The northern Guinean eco-zone lies in the Sudan eco-zone with its open wooded savannahs and perennial grasses [26,25], which gives way to the annual grasses of the drier Sahel ecozone [27]. The Saharan eco-zone (which is North of the Sahel) is marked by sparse to absent vegetation and with less than $150 \mathrm{~mm}$ precipitation p.a. [28].

\subsubsection{Temperature effects}

Temperature across WA is strongly determined by global ocean sea surface temperature (SST) [23]. Over recent decades, a clear warning signal has emerged across some regions, with the Gulf of Guinea and the west Sahel experiencing the greatest rates of warming of $0.2-0.5^{\circ} \mathrm{C}$ per decade since the $1980 \mathrm{~s}$ [29]. In contrast, there appear to have been no significant changes in the southern Sahara and the northern Sahel [29]. 
Within the next 20-30 years, the region's semi-arid and arid zones (i.e., Sahel and Saharan eco-zones) may serve as future warming hotspots, where the annual mean temperature may increase by an additional $2-4{ }^{\circ} \mathrm{C}$ under a higher greenhouse gas emissions pathway [30,31]. During the last three decades of the 21 st century, $60 \%$ of summer months across Sub-Saharan Africa are projected to be hotter than five standard deviations above the 19511980 baseline under the high-emissions pathway [32]. In contrast, most of these extremes are likely to be avoided under a low-emissions pathway [32].

\subsubsection{Precipitation trends}

The Sahel and the Saharan eco-zones typically have a single rainy season each year, around July. In contrast, the Guinean and Guineo-Congolian eco-zones have two wet seasons. The first generally runs from late April to early May, when the West African monsoon brings rain along the Atlantic Guinean coast [33], while the second rainy season extends from June to early July, after which it returns to the Sahel eco-zone within days [34].

Precipitation variability characterizes rainfall throughout WA, with substantial shifts from wet to dry periods. For example, patterns cycled from a wet period throughout the 1930s-1960s to the devastating droughts of the 1970s-1980s, with consequential impacts on the people, agricultural production, and the environment [35]. Precipitation then swung back to a more 'normal' regime in the mid-1990s (relative to the 1901-1998 average) [30].

Simulations of changes to the African Monsoon between 2030 and 2070 indicate that precipitation may decrease in the western Sahel and increase in the central-eastern Sahel [36]. Toward the end of this century, daily precipitation is projected to decline over the Gulf of Guinea [37]. According to Ekwezuo et al. [38], the West African mean annual maximum and minimum rainfall patterns are $<2600 \mathrm{~mm}$ and $<50 \mathrm{~mm}$ respectively. The projected changes in the mean annual rainfall pattern show that the amount of rainfall increases over the Guinea coast and decreases inland [38]. However, there is considerable variation regarding future precipitation patterns in the region, with projections from climate models spanning -30 and $30 \%$ of baseline levels, although larger variations are expected in the Sahel [29].

\subsubsection{Climate change projections for West Africa under alternate RCPs and GCM (i.e., emissions scenarios and climate models)}

WA is subject to uncertainties associated with the Global Climate Models (GCMs) [39]. According to Macadam et al. [39], this is primarily due to the use of different climatic variables for parametrization schemes, resulting in substantial uncertainties in GCM projections. For instance, under the Representative Concentration Pathway 8.5 (RCP8.5), models that project the temperature in the Sahel eco-zone will increase between $<0.5$ and $4{ }^{\circ} \mathrm{C}$ by 2040 2065, relative to 1951-2000 [40]. However, this increase in temperature may be less for other eco-zones within the region [7]. For instance, the IPCC Fifth Assessment Report [41] showed that under RCP8.5, the northern part of the region towards the Sahara Desert is likely to have an increase of 4 to $7^{\circ} \mathrm{C}$ by 2081 to 2100 from the baseline of 1986 to 2005 . However, the southern part towards the coast is likely to have a smaller increase of between 2 and $3{ }^{\circ} \mathrm{C}$ within the same period. Under RCP8.5, GCMs project an average increase in annual precipitation of 10 to $50 \%$ across the northwest region of WA by 2081-2100, which compares to the 1986-2005 baseline. However, there is little consensus across GCMs in the direction of change. In the southern and eastern parts of the region, towards the coast, the precipitation changes are projected to be between -10 and $+10 \%$ during the same period [41].

Projections for the future indicate that there may be a general increase in heatwaves, both in frequency and intensity, over the West African region [42]. Studies on the present climatic conditions indicate that areas within the Guinea eco-zones of WA are less likely to experience heatwaves than areas further north, such as the southern Sahel 
and the northern Sahara [43]. Similarly, the number of days with heatwaves in the future will likely be higher over the Sahel and Sahara Desert eco-zones than in the Guinea eco-zones $[42,43]$. This increase in heatwaves may have potentially important implications for food security and crop diversity in the WA region. This is inferred from previous modelling studies that suggested reductions in crop yields due to increases in temperatures [44]. However, interacting climatic factors, such as rainfall distribution, episodic drought, humidity and evaporation rates, will also influence the outlook for food production.

\subsection{Major horticultural crops in West Africa}

In WA, the horticultural crops with the highest production in terms of tonnes are root and tuber crops. According to FAOSTAT [45], over 93 million tonnes of cassava (Manihot esculenta Crantz) and 66 million tonnes of yam (Dioscorea species) were produced in the region in 2018. Excluding cereals and legumes, between 2-10 million tonnes of 12 other horticultural crops were also produced in 2018: plantain (Musa paradisiaca) ( $>9.7$ million), sugar cane (Saccharum species) (>6.7), sweet potato (Ipomoea batatas (L.) Lam.) (>5.5), tomato (Solanum lycopersicum L.) (>5.2), taro (Colocasia esculenta (L.) Schott) (>5.0), cocoa bean (Theobroma cacao L.) (>3.3), pineapple (Ananas comosus (L.) Merr.) (>2.9), okra (Abelmoschus esculentus (L.) Moench) (>2.7), onion (Allium cepa L.) (> 2.7), mango (Mangifera species) (>2.5), and potato (Solanum tuberosum L.) ( $>2.1$ ).

In general, countries within Guinea and Sudan eco-zones of WA produce crops at a higher yield than those within the Sahel and Saharan eco-zones, particularly for root and tuber crops (cassava, yam and taro). Further, West African countries are among the world's leading producers of yam and taro (Fig. 2). In the following sections, horticultural crops are classified as vegetables, plantation, fruit, and root and tuber crops, while the potential consequences of climate change on them are assessed.

\subsubsection{Vegetable crops}

As with other crops, the production of vegetables depends mainly on soil quality and climate [46], with climate also influencing the development and condition of the soil through weathering [47]. Vegetables are generally highly sensitive to environmental extremes [48], and increases in temperature will be a serious threat to these crops in WA [49] both directly and by exacerbating soil dryness [50]. Crops such as tomatoes grown in Sahel regions of WA already experience conditions at their upper optimal thermal margin. Additional increases in temperature will, therefore, result in lower yield [51].

Other important vegetable crops that may be affected by the projected increase in temperature and dryness are peppers, onions, watermelons, and carrots [52]. However, crop responses will depend on the plant growth stage and the exposure time to the stressing agent [53]. Under limited water conditions, low water-use vegetables such as Tepary beans (Phaseolus acutifolius), black-eyed beans (Vigna unguiculata), okra (Abelmoschus esculentus), and asparagus (Asparagus officinalis) are likely to have higher survival rates [54].

\subsubsection{Plantation crops}

Plantation crops, also referred to as perennial horticultural crops (e.g., banana [Musa sp.], plantain [Musa paradisiaca], cocoa [Theobroma cacao]), are extremely sensitive to changes in temperature, water availability, solar radiation, air pollution, and $\mathrm{CO}_{2}$ [55]. This sensitivity affects both the quantity and quality of their harvested produce. Also, increased temperature, together with dryness and drought, can be a serious growth hindrance for plantation crops, reducing fruit and leaf development, and may increase plant mortality [56]. 


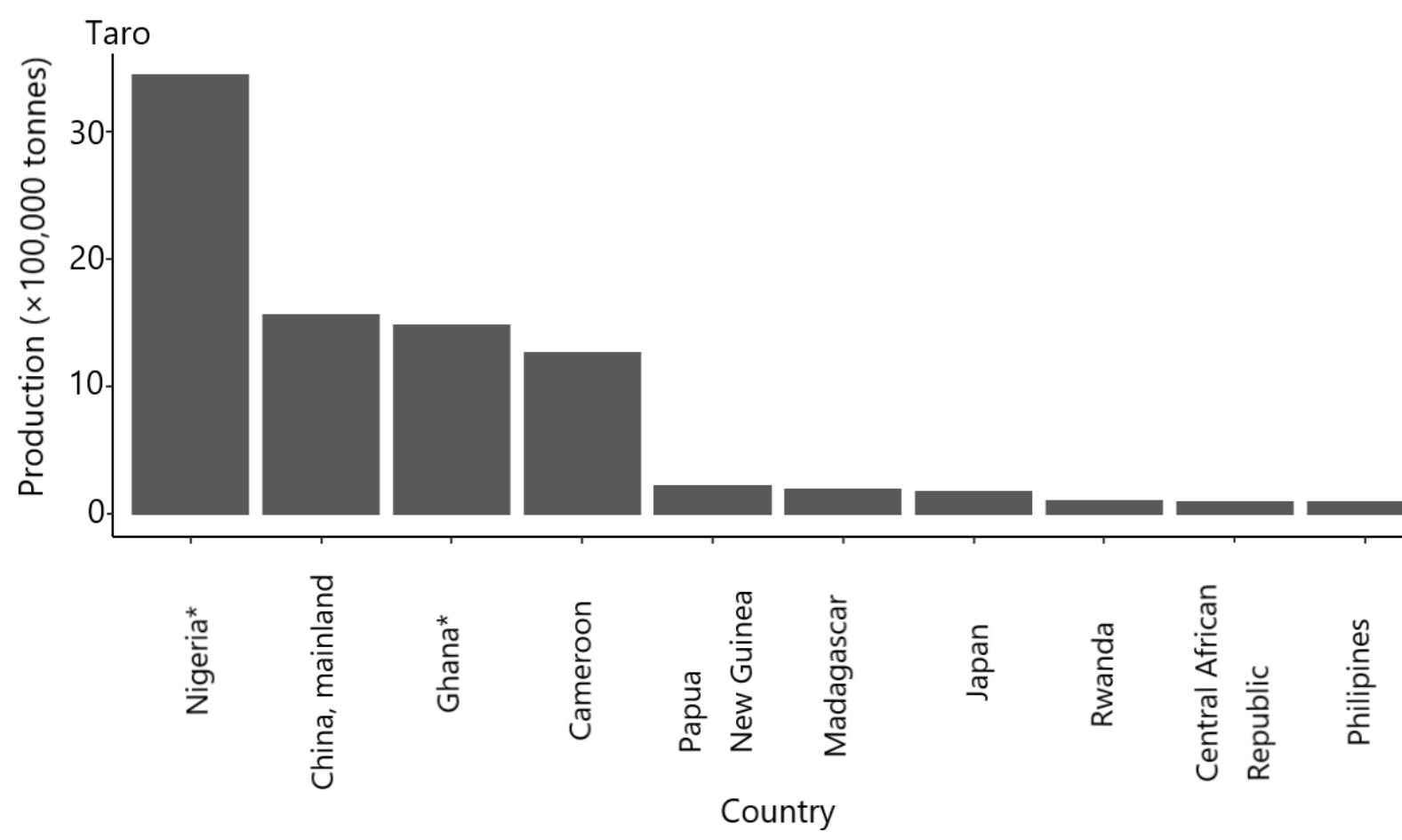

Figure 2a: Global leading producers of Taro (Colocasia esculenta (L.) Schott)

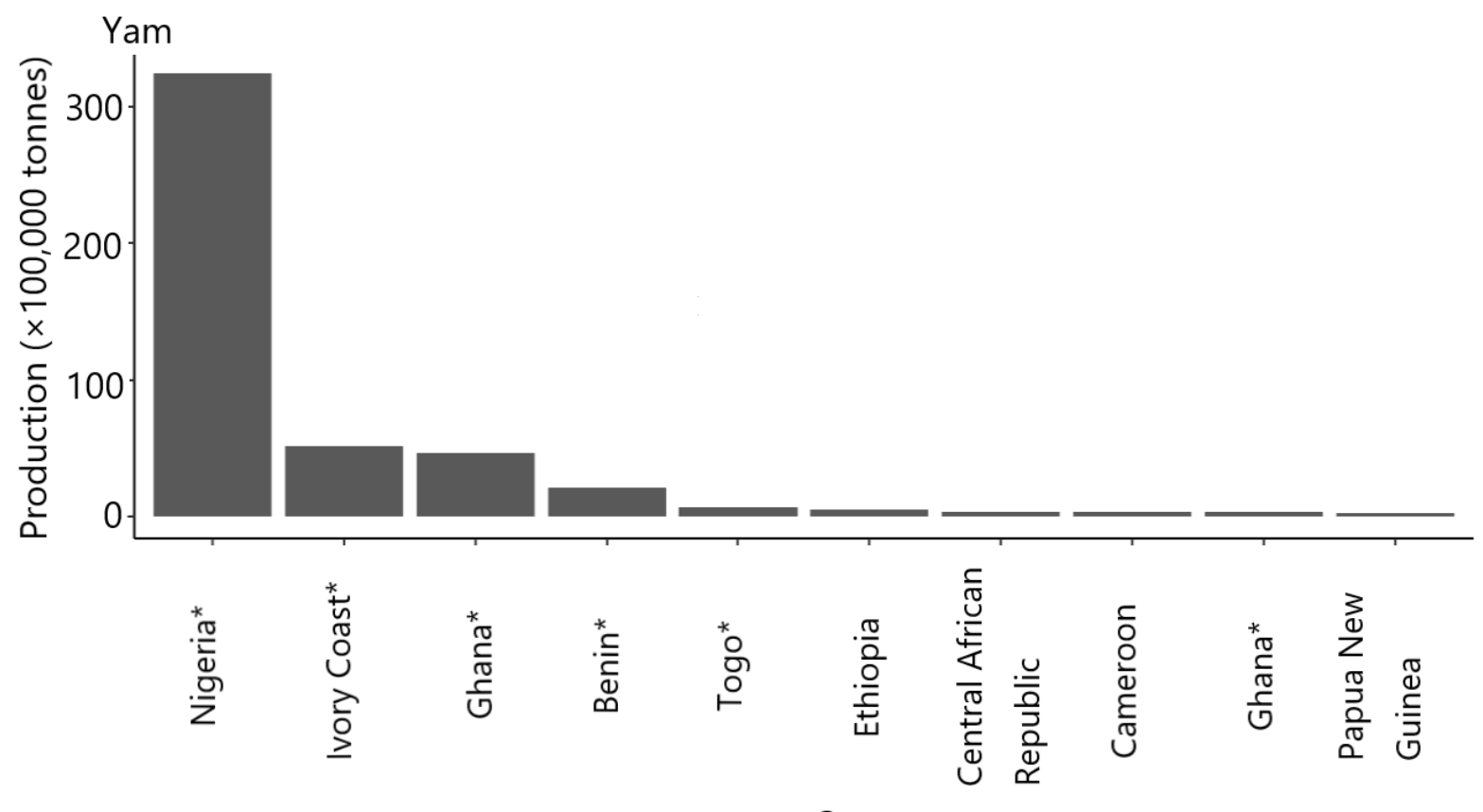

Country

Figure 2b: Global leading producers of Yam (Dioscorea species) 


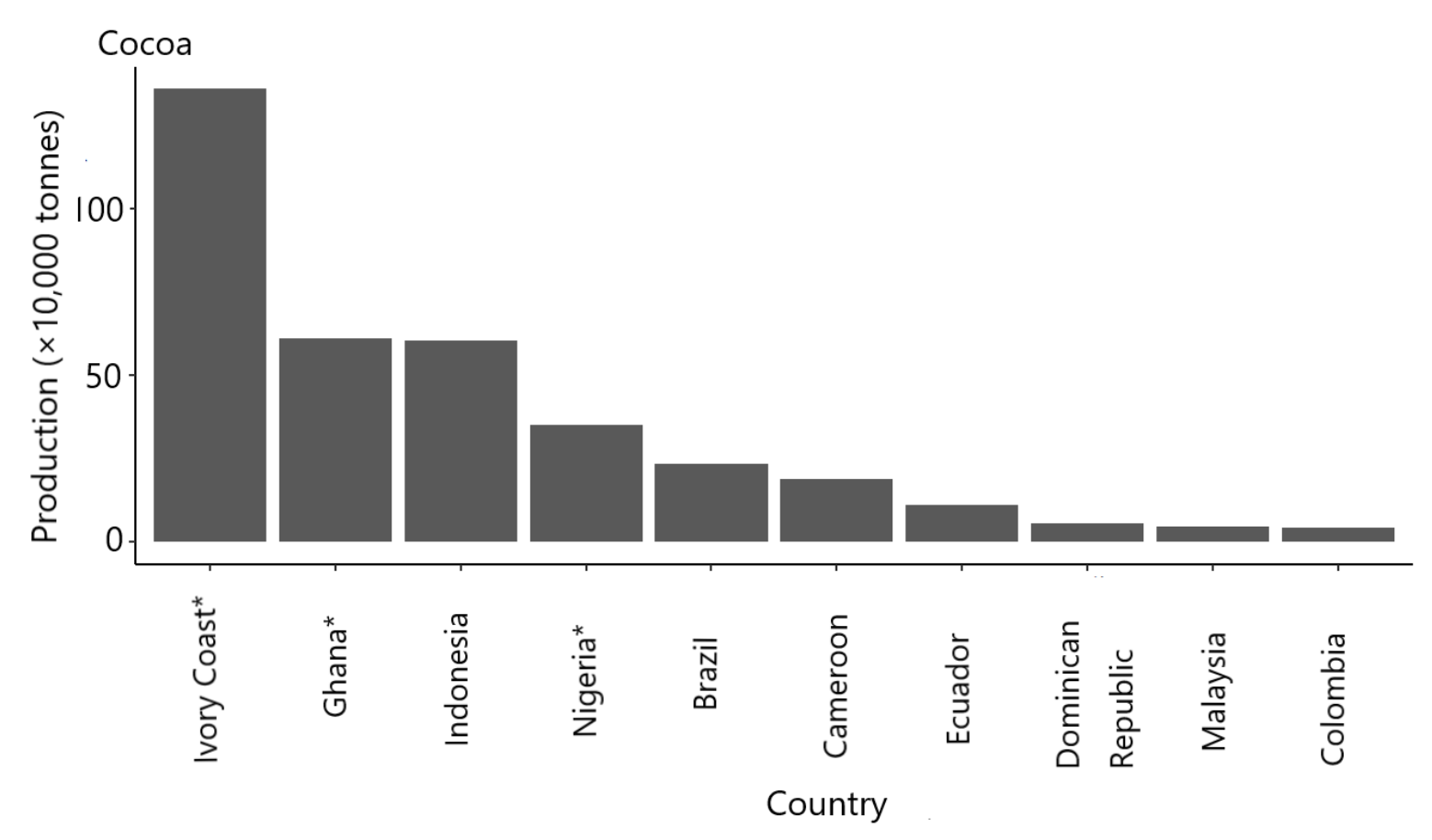

Figure 2c: Global leading producers of Cocoa (Theobroma cacao L.)

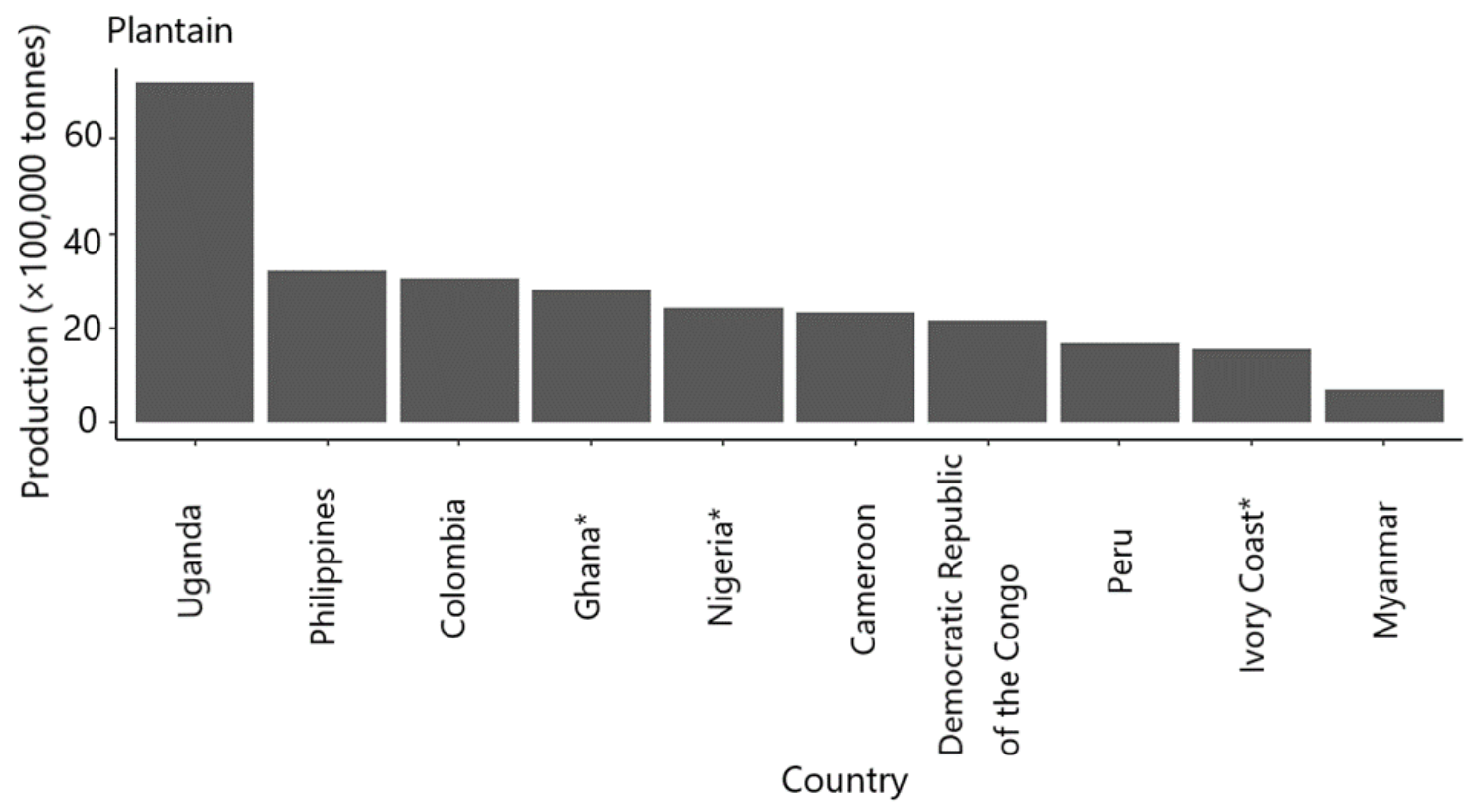

Figure 2d: Global leading producers of Plantain (Musa paradisiaca)

Figure 2: Global leading producers of key horticultural crops. Average 1994-2017.

$\mathrm{Y}$-axis=total production in tonnes, $\mathrm{X}$-axis=Global leading top 10 producing countries. ${ }^{*}$ Countries in WA [45]. 
Banana, plantain, and cocoa are important components of diets among West Africans. These crops provide essential nutrients, including vitamins, fiber, and anti-oxidants [57], which often are limited in cereals [55]. These crops are also very important for local and national economies [58]. Lower rainfall will affect the growth and development of bananas and plantain [59], with subsequent declines in yield. Conversely, should projected increases in precipitation across parts of the Sahel be realized, these crops may have a higher yield [37].

WA contributes about $<70 \%$ of the total global cocoa supply [60], which is projected to increase by $3.7 \%$ in the next 50 to 70 years [61]. This increase is considerably more than the increase in other regions of the world (e.g., 3.1\% in America, 1.5\% in Asia and Oceania [61]. However, if the projected future declines in precipitation exceed $110 \mathrm{~mm}$ per month with increases in the frequency and intensity of drought events, there will be substantial impacts on the yield of this drought-intolerant crop [62,63].

\subsubsection{Fruit crops}

In general, fruit crops such as mango, guava, and especially citrus are likely to benefit from higher concentrations of $\mathrm{CO}_{2}$ due to the 'fertilization effect' that this gas has on plant ecophysiology [64]. However, the ability to realize positive responses to higher $\mathrm{CO}_{2}$ may be offset depending upon the magnitude of temperature and precipitation changes. For instance, temperatures above $30^{\circ} \mathrm{C}$ can cause premature ripening in mango, while dryness can induce a reduction in leaf initiation, leaf size and thickness in citrus [65,66].

For most fruit crops, particularly those originating in the tropics, which are adapted to temperatures of up to $30{ }^{\circ} \mathrm{C}$, deviations from their required optimum are likely to negatively affect production and quality, while those crops currently limited by low temperature are likely to benefit from warming [67].

\subsubsection{Root and tuber crops}

Root and tubers make a substantial contribution to the diet of people in WA, with cassava, yam, and sweet potatoes being key crops in this category. Yam, for example, plays an important role in food security and the livelihood of more than 60 million people within the region [68]. In addition, West African countries contribute substantially to the global market for these crops [69]. For instance, Benin, Ivory Coast, Ghana, Nigeria, and Togo currently produce about 57 million tons of yam (about 93\% of global production), and Nigeria accounts for approximately $68 \%$ of the global production (40.5 million tons produced across 3.2 million ha) [68] (see Fig. 2).

Models of yam yield under climate change scenarios suggest that the optimal temperatures for this crop (between $25-30^{\circ} \mathrm{C}$ ) are likely to continue to occur in WA until at least around the end of the first half of this century [70]. However, compared to the baseline of 1961-2000, yam yields across the savannah zone are projected to decrease to $18-48 \%$ by $2041-2050$ due to reduced precipitation and nitrogen deficiency [71].

For cassava, increases of more than $1.5^{\circ} \mathrm{C}$ in the mean annual temperature could negatively impact production [72]. In addition, glasshouse experiments indicate that plant biomass and tuber yield decline with higher $\mathrm{CO}_{2}$ concentrations due to a decrease in assimilation [73]. Furthermore, concentrations of cyanogenic glycosides in the leaves of this crop also increase under high $\mathrm{CO}_{2}$ concentrations, indicating that, to remain edible, the leaves may need processing in the future [73].

While used as a food source within West African countries, sweet potato is not yet a regional or internationally traded crop from WA [68]. Both sweet potato and cassava are relatively drought-tolerant, although tuber yield and starch content may be reduced when rainfall is limited [66]. Hence, regions where precipitation has been projected to decline (e.g., southern and western parts of Sahel) may experience lower yields of these crops in the future [36,37]. 


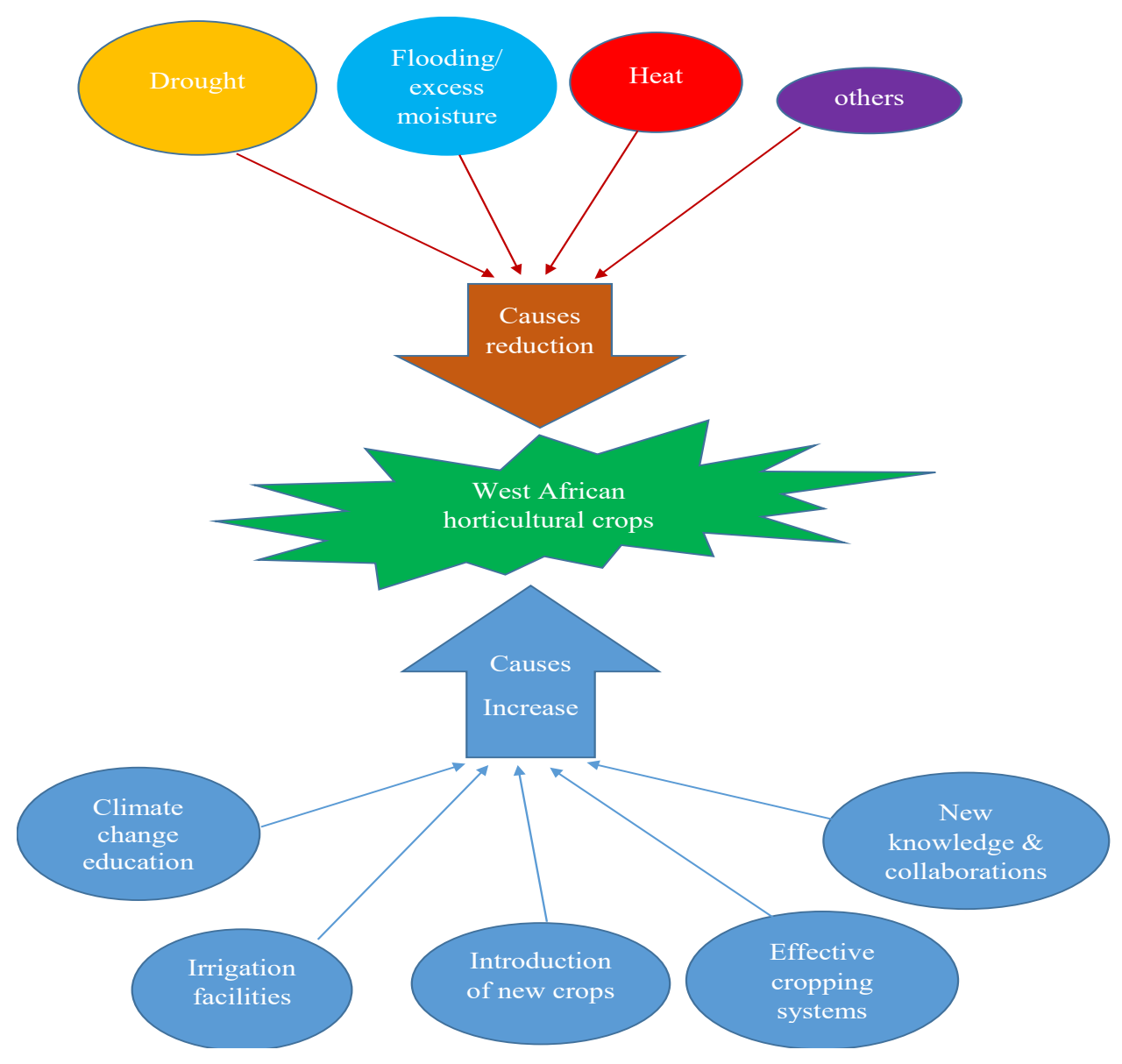

Figure 3: Ways climate change can negatively affect future horticultural crops production in West Africa (WA) and possible ways to address it

\subsection{Recommended adaptation strategies for WA horticulture}

In WA, there is considerable effort in developing measures to mitigate the effects of climate change. One example of these measures is the formation of the West African Science Service Centre on Climate Change and Adapted Land Use (WASCAL), which is a large-scale research center designed to tackle the climate change challenges in the region. WASCAL's main objective is to undertake research on adapting land use and management of land given the region's changing climatic conditions (https://wascal.org/). However, a considerable number of areas have not been fully addressed or need to be improved upon, as outlined below.

\subsubsection{Climate change education}

Climate change education must increase and be reachable for all the stakeholders involved in horticultural crop production in WA, especially the farmers. This is very important as many studies have shown that farmers' perceptions of climate change and adaptation influence the success of mitigation strategies [74,75,76]. In a region where illiteracy levels are very high, there is an urgent need to increase the scope and means of conveying 
information about changing climate adaptation and mitigation strategies to the people who need it most, namely the farmers. This task can be achieved through organizing workshops, seminars, conferences, compulsory formal classes for lower and higher school levels, and informal sensitization campaigns through the mass media like television, radios, posters, etc. [77].

\subsubsection{Provision of irrigation facilities}

Supplementary water provision may be necessary for the success of some horticultural industries in WA, particularly in those areas where seasonal precipitation may decrease and episodes of drought increase, such as the southern Sahel [37]. This provision will likely be vital for succulent horticultural crops, such as vegetables, which are significantly affected by limited water conditions or stress [78]. However, the expansion of irrigation facilities will require investment by governments and international agencies.

\subsubsection{Introduction of new cultivars}

There is a critical need to improve the understanding of the physiological and genetic basis of crop adaptation to abiotic stress caused by climate change. As the climatic suitability of a region for its current suite of crops changes, different cultivars may prove more suited. This may necessitate a broader selection of crops being made available through breeding or the introduction of new cultivars or varieties.

\subsubsection{Adoption/development of effective cropping system}

Climate change is likely to drive adjustments to crop production areas and timing of planting, illustrating the need to educate farmers on both the impacts and strategies for effective cropping system and ensuring that market mechanisms are in place should farmers need to adjust the range of crops they plant. Other management practices such as crop rotation, soil management and conservation, and effective handling of pests and disease infestation should be promoted to mitigate the adverse effects of climate change.

\subsubsection{Improve research on climate change}

Research on climate change must be supported and encouraged. This strand of research should aim to develop new farming systems and sustainable alternatives for agricultural activities. More grants and funding availability will also increase research in the area of possible effects of climate change on horticulture in the region.

\subsubsection{Transferring and implementing new techniques/knowledge/skills from other regions/countries}

Efforts should be made at regional and national levels to assess and implement adaptation programs adopted by other countries/regions. Many developed countries have already gained substantial knowledge on the adaptation of horticultural crops to climate change, and the transfer of knowledge/lessons learned from these regions may help to reduce knowledge gaps in the WA region $[79,80]$.

\subsubsection{Proper collaborations}

All stakeholders involved in horticultural industries, including farmers and those in the public and private sectors, should partner to generate and communicate management strategies in the region. This should involve organizations such as FAO, CGIAR (Consultative Group for International Agricultural Research), UNEP (The United Nations Environment Programme) and WASCL. An example of such an initiative already in existence is the 'Forum for the Future' programme (www.forumforthefuture.org). This non-government organization collaborates with 
governments, corporate businesses, and civil societies to achieve a sustainable future. A holistic approach is needed in tackling the impacts of climate change to ensure that all sectors of horticultural production are addressed [81].

\section{Conclusion}

The effect of climate change on the horticultural crops grown in WA under rain-fed conditions will likely be negatively drastic (Fig.3). The global changes in climatic conditions, which cause drought, excess precipitation/flooding and heat [82], possibly have the strongest impact on the production of horticultural crops in WA. The fact that these changes in global climate may affect horticultural crops growth and agricultural production, in general, is concerning. Evidence from the reviewed studied indicate that the impact of the projected changes in the West African climate can cause real environmental stress, which might lead to a decrease in plants growth and development.

For some WA eco-zones (e.g., the Sahel), future climate scenarios predict increases in precipitation [83], which will likely have positive impacts on crop yields if temperature increases are not severe. However, across other regions, higher levels of temperature and lower precipitation, combined with increases in the frequency and severity of extreme events, may have catastrophic consequences on the development of rain-fed horticultural crops. The uncertainty surrounding precipitation scenarios necessitates that drastic and bold adaptation programmes be developed. As the climate continues to change, the continuous production of horticultural crops in their current regions under natural rain-fed conditions may no longer be sustainable.

\section{Acknowledgements}

This study was supported by a scholarship and research funding from the International Research Training Program (iRTP) for my doctorate (Student Number: 44734344) in the Department of Biological Sciences, Faculty of Science and Engineering, Macquarie University, Sydney, Australia. The author also wishes to thank his doctorate degree supervisors: Associate Professor Linda Beaumont and Professor Brian Atwell, for their technical input in the work.

\section{REFERENCES}

[1] Guan K, Sultan B, Biasutti M, Baron C and Lobell DB (2017) Assessing climate adaptation options and uncertainties for cereal systems in West Africa. Agricultural and Forest Meteorology, 232: 291-305. https://doi.org/10.1016/j.agrformet.2016.07.021

[2] Diasso U and Abiodun BJ (2017) Drought modes in West Africa and how well CORDEX RCMs simulate them. Theoretical and Applied Climatology, 128: 223-240. DOI 10.1007/s00704-015-1705-6

[3] Butler RA and Laurance WF (2008) New strategies for conserving tropical forests. Trends in Ecology and Evolution, 23(9): 469-472. https://doi.org/10.1016/j.tree.2008.05.006

[4] Sultan B, Guan K, Kouressy M, Biasutti M, Piani C, Hammer GL, McLean G and Lobell B (2014) Robust features of future climate change impacts on sorghum yields in West Africa. Environmental Research Letters, 9: 104006. DOI:10.1088/17489326/9/10/104006

[5] Niang I, Ruppel OC, Abdrabo MA, Essel A, Lennard C, Padgham J and Urquhart P (2014) Africa. In: Climate change 2014: Impacts, adaptation, and vulnerability. Part B: Regional aspects. Contribution of working group II to the fifth assessment report of the intergovernmental panel on climate change [Barros VR, Field CB, Dokken DJ, Mastrandrea MD, Mach KJ, Bilir TE, Chatterjee M, Ebi KL, Estrada YO, Genova RC, Girma B, Kissel ES, Levy AN, MacCracken S, Mastrandrea PR and White LL (eds.)], pp.1199-1265. Cambridge University Press, Cambridge, United Kingdom and New York, NY, USA.

[6] Turco M, Palazzi1 E, Von-Hardenberg J and Provenzale A (2015) Observed climate change hotspots. Geophysical Research Letters, 42 (9): 3521-3528. DOI:10.1002/2015GL063891

[7] Sultan B and Gaetani M (2016) Agriculture in West Africa in the twenty-first Century: climate change and impacts scenarios, and potential for adaptation. Frontiers in Plant Science, 7: 1262. DOI: 10.3389/fpls.2016.01262 
Please cite this article as

Amuji. Reviews in Agricultural Science, 9: 206-220, 2021

https://dx.doi.org/10.7831/ras.9.0_206

[8] Joiner E, Kennedo D and Sampson J (2012) Vulnerability to climate change in West Africa: Adaptive capacity in the regional context. Climate Change and African Political Stability Student Working Paper, 4: 43. The University of Texas Austin, Texas 78712, USA.

[9] Barry AA, Caesar J, Klein T, Aguilar E, McSweeney C, Cyrille AM, Nikiema MP, Narcisse KB, Sima F, Stafford G and Touray LM (2018) West Africa climate extremes and climate change indices. International Journal of Climatology, 38: 921-938. DOI: 10.1002/joc. 5420

[10] United States Agency for International Development-USAID (2018) Report titled 'Climate change adaptation in Western Africa'. Available online at https://www.climatelinks.org/resources/climate-change-adaptation-west-africa-fact-sheet Retrieved on $6 / 11 / 2019$

[11] United Nations (2018) Department of economic and social affairs, population division 2017. World Population Prospects 2017 Data Booklet (ST/ESA/SER.A/401).

[12] Knippertz P, Evans MJ, Field PR, Fink AH, Liousse C and Marsham JH (2015) The possible role of local air pollution in climate change in West Africa. Nature Climate Change, 5(9): 815-822.

[13] Hollinger F and Staatz JM (2015) Agricultural growth in West Africa, market and policy drivers. Co-published by the African development bank and the food and agriculture organization of the United Nations. Rome, Italy.

[14] Asare-Kyei D, Renaud FG, Kloos J, Walz Y and Rhyner J (2017) Development and validation of risk profiles of West African rural communities facing multiple natural hazards. PloS One, 12(3): e0171921. https://doi.org/10.1371/journal.pone.0171921

[15] Blein R and Bwalya M (2013) Agriculture in Africa: Transformation and outlook. New Partnership for African Development. (NEPAD) Report Publication. Johannesburg, South Africa. Retrieved from: http://www.un.org/en/africa/osaa/pdf/pubs/2013africanagricultures.pdf

[16] Sossa A, Liebmann B, Blade I, Allured D, Hendon HH, Peterson P and Hoell A (2017) Statistical connection between the Madden-Julian oscillation and large daily precipitation events in West Africa. Journal of Climate, 30 (6): 1999-2010. https://doi.org/10.1175/JCLI-D-16-0144.1

[17] Okpara UT, Stringer LC and Dougill AJ (2016) Perspectives on contextual vulnerability in discourses of climate conflict. Earth System Dynamics, 7(1): 89-102. DOI:10.5194/ESD-7-89-2016

[18] Olomola A, Mogues T, Olofinbiyi T, Nwoko C, Udoh E, Alabi R, Onu J and Woldeyohannes S (2014) Agriculture public expenditure review at the federal and subnational levels in Nigeria (2008-12). World Bank, Washington, DC., USA.

[19] Von Baeyer E (2014) The development and history of horticulture. World Environmental History edited by Agnoletti M, Johann E and Serneri S, EOLSS Publisher, Oxford, UK.

[20] Olasantan FO (2011) Horticulture: the under exploited goldmine in Africa. Inaugural Lecture Series, No. 31. Publications of University of Agriculture, Abeokuta, Nigeria.

[21] Levy BS and Patz JA (2015) Climate change, human rights, and social justice. Annals of Global Health, 81 (3): 310-322.

[22] Deryng D, Sacks WJ, Barford CC and Ramankutty N (2011) Simulating the effects of climate and agricultural management practices on global crop yield. Global Biogeochemical Cycles, 25(2): 1-18. DOI:10.1029/2009GB003765

[23] Pomposi C, Kushnir Y and Giannini A (2015) Moisture budget analysis of SST-driven decadal Sahel precipitation variability in the twentieth century. Climate Dynamics, 44: 3303-3321.

[24] Hansen MC, Stehman SV, Potapov PV, Loveland TR, Townshend JRG, DeFries RS, Pittman KW, Arunarwati B, Stolle F, Steininger MK, Carroll M and DiMiceli C (2008) Humid tropical forest clearing from 2000 to 2005 quantified by using multitemporal and multiresolution remotely sensed data. Proceedings of the National Academy of Sciences, 105(27): 94399444. DOI: 10.1073PNAS.0804042105

[25] Akinsanola A and Ogunjobi K (2017) Evaluation of present-day rainfall simulations over West Africa in CORDEX regional climate models. Environmental Earth Sciences, 76: 366. DOI 10.1007/s12665-017-6691-9

[26] Diaconescu EP, Gachon P, Scinocca J and Laprise R (2015) Evaluation of daily precipitation statistics and monsoon onset/retreat over western Sahel in multiple data sets. Climate Dynamics, 45 (5): 1325-1354. https://doi.org/10.1007/s00382-014-2383-2

[27] Alam S, Starr M and Clark BJF (2013) Tree biomass and soil organic carbon densities across the Sudanese woodland savannah: A regional carbon sequestration study. Journal of Arid Environments, 89: 67-76. https://doi.org/10.1016/j.jaridenv.2012.10.002/

[28] Cotillon SE and Tappan GG (2016) Landscapes of West Africa: A window on a changing world. United States Geological Survey, Garretson, SD, USA. 
Please cite this article as

Amuji. Reviews in Agricultural Science, 9: 206-220, 2021

https://dx.doi.org/10.7831/ras.9.0_206

[29] Sylla MB, Nikiema PM, Gibba P, Kebe I and Klutse NAB (2016) Climate change over West Africa: Recent trends and future projections. In Adaptation to climate change and variability in rural West Africa (pp. 25-40). In Yaro JA and Hesselberg J (eds.), Adaptation to climate change and variability in rural West Africa. Springer International Publishing, Basel, Switzerland. DOI: 10.1007/978-3-319-31499-0_3

[30] Sarr B (2012) Present and future climate change in the semi-arid region of West Africa: a crucial input for practical adaptation in agriculture. Atmospheric Science Letters, 13(2): 108-112. DOI: 10.1002/asl.368

[31] Mora C, Frazier AG, Longman RJ, Dacks RS, Walton MM, Tong EJ, Sanchez JJ, Kaiser LR, Stender YO, Anderson JM and Ambrosino CM (2013) The projected timing of climate departure from recent variability. Nature, 502 (7470): $183-187$.

[32] Serdeczny O, Adams S, Baarsch F, Coumou D, Robinson A, Hare W, Schaeffer MP and Reinhardt J (2017) Climate change impacts in Sub-Saharan Africa: from physical changes to their social repercussions. Regional Environmental Change, 17 (6): 1585-1600. https://doi.org/10.1007/s10113-015-0910-2

[33] Froidurot S and Diedhiou A (2017) Characteristics of wet and dry spells in the West African monsoon system. Atmospheric Science Letters, 18: 125-131. DOI: 10.1002/asl.734

[34] Cook KH (2015). Role of inertial instability in the West African monsoon jump. Journal of Geophysical Research: Atmospheres, 120(8): 3085-3102. DOI:10.1002/2014JD022579

[35] Rodríguez-Fonseca B, Janicot S, Mohino E, Losada T, Bader J, Caminade C, Chauvin F, Fontaine B, Gracia-Serrano J, Gervois S, Joly M, Polo I, Ruti P, Roucou P and Voldoire A (2011) Interannual and decadal SST-forced responses of the West African monsoon. Atmospheric Science Letters, 12 (1): 67-74. DOI: 10.1002/asl.308

[36] Monerie PA, Fontaine B and Roucou P (2012). Expected future changes in the African monsoon between 2030 and 2070 using some CMIP3 and CMIP5 models under a medium-low RCP scenario. Journal of Geophysical Research: Atmospheres, 117(D16). DOI: $10.1029 / 2012 J D 017510$

[37] Raj J, Bangalath HK and Stenchikov G (2019) West African monsoon: Current state and future projections in a high-resolution AGCM. Climate Dynamics 52 (11): 6441-6461. https://doi.org/10.1007/s00382-018-4522-7

[38] Ekwezuo CS, Nnamchi HC and Phil-Eze PO (2017) Projected changes in mean annual rainfall pattern over West Africa during the twenty first century. Pakistan Journal of Meteorology, 14 (27): 1-11.

[39] Macadam I, Rowell DP and Steptoe H (2020) Refining projections of future temperature change in West Africa. Climate Research, 82: 1-14.

[40] Rowell DP, Senior CA, Vellinga M and Graham RJ (2016) Can climate projection uncertainty be constrained over Africa using metrics of contemporary performance? Climatic Change, 134(4): 621-633. DOI 10.1007/s10584-015-1554-4

[41] Drouet L, Bosetti V and Tavoni M (2015) Selection of climate policies under the uncertainties in the Fifth Assessment Report of the IPCC. Nature climate change, 5(10): 937-940. DOI: 10.1038/NCLIMATE2721

[42] Odoulami RC, Abiodun BJ, Ajayi AE, Diasso UJ and Saley MM (2017) Potential impacts of forestation on heatwaves over West Africa in the future. Ecological Engineering, 102: 546-556.

[43] Sylla MB, Faye A, Giorgi F, Diedhiou A and Kunstmann H (2018) Projected heat stress under $1.5{ }^{\circ} \mathrm{C}$ and $2{ }^{\circ} \mathrm{C}$ global warming scenarios creates unprecedented discomfort for humans in West Africa. Earth's Future, 6(7): 1029-1044.

[44] Sultan B, Roudier P, Quirion P, Alhassane A, Muller B, Dingkuhn M, Ciais P, Guimberteau M, Traore S and Baron C (2013) Assessing climate change impacts on sorghum and millet yields in the Sudanian and Sahelian savannas of West Africa. Environmental Research Letters, 8(1): 014040. DOI:10.1088/1748-9326/8/1/014040

[45] FAOSTAT (2019) Food Agriculture and Organization (FAOSTAT). Retrieved from http://www.fao.org/faostat/en/\#data/RF

[46] Prodhan AZMS, Islam MS and Islam MM (2018) Effect of soil and environment on winter vegetables production. Food Process Technology, 6 (4): 384-389. DOI:10.15406/mojfpt.2018.06.00192

[47] Dixon JL, Heimsath AM and Amundson R (2009) The critical role of climate and saprolite weathering in landscape evolution. Earth Surface Processes and Landforms, 34: 1507-1521. DOI: 10.1002/esp.1836

[48] De la Pena R and Hughes J (2007) Improving vegetable productivity in a variable and changing climate. Journal of SAT Agricultural Research, 4(1): 1-22.

[49] Diallo I, Giorgi F, Deme MT, Mariotti L and Gaye AT (2016). Projected changes of summer monsoon extremes and hydroclimatic regimes over West Africa for the twenty-first century. Climate Dynamics, 47 (12): 3931-3954. https://doi.org/10.1007/s00382-016-3052-4 
Please cite this article as

Amuji. Reviews in Agricultural Science, 9: 206-220, 2021

https://dx.doi.org/10.7831/ras.9.0_206

[50] Monerie PA, Biasutti M and Roucou P (2016) On the projected increase of Sahel rainfall during the late rainy season. International Journal of Climatology, 36 (13): 4373-4383. DOI: 10.1002/joc.4638

[51] Amuji CF, Beaumont LJ and Rodriguez ME (2020) Simulating the impact of projected West African heatwaves and water stress on the physiology and yield of three tomato varieties. Advances in Horticultural Sciences, 34(2): 147-156. DOI: 13128/ahsc8494

[52] Erickson A and Markhart A (2002) Flower developmental stage and organ sensitivity of bell pepper (Capsicum annuum L.) to elevated temperature. Plant, Cell and Environment, 25(1): 123-130.

[53] Pandey P, Irulappan V, Bagavathiannan MV and Senthil-Kumar M (2017) Impact of combined abiotic and biotic stresses on plant growth and avenues for crop improvement by exploiting physio-morphological traits. Frontiers in Plant Science, 8: 537. DOI: $10.3389 /$ fpls.2017.00537

[54] Elias EH, Flynn R, Idowu OJ, Reyes J, Sanogo S, Schutte BJ, Smith R, Steele C and Sutherland C (2019) Crop vulnerability to weather and climate risk: Analysis of interacting systems and adaptation efficacy for sustainable crop production. Sustainability, 11(23): 6619. DOI:10.3390/su11236619

[55] Glenn M, Kim S, Ramirez-Villegas J and Laderach P (2013) Response of perennial horticultural crops to climate change. Horticultural Reviews, 41: 47-130.

[56] Ranjitkar S, Sujakhu NM, Budhamagar K, Rimal S, Xu J, Merz J and Zomer RJ (2015) Projected climate change impacts on climatic suitability and geographical distribution of banana and coffee plantations in Nepal. World Agroforestry Centre (ICRAF): Nairobi, Kenya.

[57] Martínez-Cardozo C, Cayon-Salinas G and Ligarreto-Moreno G (2016) Chemical composition and distribution of dry matter in genotypes of banana and plantain fruits. Corpoica Ciencia y Tecnología Agropecuaria, 17(2): 217-227.

[58] Brun TA (1991) The nutrition and health impact of cash cropping in West Africa: a historical perspective. World Review of Nutrition and Dietetics, 65: 124-162. DOI: 10.1159/000419470

[59] German C, Staver GC and Siles P (2015) An assessment of global banana production and suitability under climate change scenarios, In Climate change and food systems: global assessments and implications for food security and trade, Aziz Elbehri (editor). Food Agriculture Organization of the United Nations (FAO) publications, Rome, Italy.

[60] Schroth G, Läderach P, Martinez-Valle AI and Bunn C (2017) From site-level to regional adaptation planning for tropical commodities: cocoa in West Africa. Mitigation and Adaptation Strategies for Global Change, 22(6): 903-927. https://doi.org/10.1007/s11027-016-9707-y

[61] The International Cocoa Organization ICCO (2018) May 2018 Quarterly Bulletin of Cocoa Statistics. Retrieved from: https:/www.icco.org/about-us/icco-news/389-may-2018-quarterly-bulletin-of-cocoa-statistics.html

[62] Carr M and Lockwood G (2011) The water relations and irrigation requirements of cocoa (Theobroma cacao L.): a review. Experimental Agriculture, 47(4): 653-676.

[63] Gateau-Rey L, Tanner EV, Rapidel B, Marelli JP and Royaert S (2018) Climate change could threaten cocoa production: Effects of 2015-16 El Niño-related drought on cocoa agroforests in Bahia, Brazil. PloS One, 13(7): e0200454. https://doi.org/10.1371/journal.pone.0200454

[64] Downton WJS, Grant WJR and Loveys BR (1987) Carbon dioxide enrichment increases the yield of Valencia orange. Functional Plant Biology, 14(5): 493-501.

[65] Rajan S (2012) Phenological responses to temperature and rainfall: A case study of mango. Bioversity International Office for South Asia, National Agricultural Science Centre, DPS Marg, Pusa Campus, New Delhi 110 012, India.

[66] Malhotra S (2017) Horticultural crops and climate change: A review. Indian Journal of Agricultural Sciences, 87(1): 12-22.

[67] Nath V, Kumar G, Pandey SD and Pandey S (2019) Impact of climate change on tropical fruit production systems and its mitigation strategies. In: Sheraz Mahdi S (eds) Climate change and agriculture in India: Impact and Adaptation. Springer, Cham, Basel, Switzerland.

[68] Sanginga M (2015) Root and tuber crops (cassava, yam, potato and sweet potato). Proceedings of an Action Plan for African Agricultural Transformation Conference, Dakar, Senegal.

[69] Merem EC, Twumasi YA, Wesley J, Olagbegi D, Crisler M, Romorno C, Alsarari M, Isokpehi P, Hines A, Ochai GS and Nwagboso E (2020) Exploring cocoa farm land use in the West African region. International Journal of Agriculture and Forestry, 10(1): 19-39. DOI: 10.5923/j.ijaf.20201001.03 
[70] Srivastava AK, Gaiser T and Ewert F (2016) Climate change impact and potential adaptation strategies under alternate climate scenarios for yam production in the sub-humid savannah zone of West Africa. Mitigation and Adaptation Strategies for Global Change, 21: 955-968. https://doi.org/10.1007/s11027-015-9639-y

[71] Srivastava AK, Gaiser T, Paeth H and Ewert F (2012) The impact of climate change on Yam (Dioscorea alata) yield in the savanna zone of West Africa. Agriculture, Ecosystems and Environment, 153:57-64. https://doi.org/10.1016/j.agee.2012.03.004

[72] El-Sharkawy MA (2003). Cassava biology and physiology. Plant Molecular Biology, 53(5): 621-641.

[73] Gleadow RM, Evans JR, McCaffery S and Cavagnaro TR (2009) Growth and nutritive value of cassava (Manihot esculenta Cranz.) are reduced when grown in elevated $\mathrm{CO}_{2}$. Plant Biology, 11: 76-82. https://doi.org/10.1111/j.1438-8677.2009.00238.x

[74] Niles MT and Mueller ND (2016) Farmer perceptions of climate change: Associations with observed temperature and precipitation trends, irrigation, and climate beliefs. Global Environmental Change, 39:133-142. https://doi.org/10.1016/j.gloenvcha.2016.05.002

[75] Hitayezu P, Wale E and Ortmann G (2017) Assessing farmers' perceptions about climate change: A double-hurdle approach. Climate Risk Management, 17:123-138. https://doi.org/10.1016/j.crm.2017.07.001

[76] Waibel H, Pahlisch TH and Völker M (2018) Farmers' perceptions of and adaptations to climate change in Southeast Asia: the case study from Thailand and Vietnam. In Climate smart agriculture (pp.137-160). Springer, Cham, Basel, Switzerland.

[77] Mailumo D, Igbe S and Mailumo P (2018) Climate change education for sustainable development: Lessons for Nigeria. In: Leal Filho W (eds) Handbook of climate change resilience. Springer, Cham, Basel, Switzerland. DOI: 10.1007/978-3-319-710259_170-1

[78] Waśkiewicz A, Gladysz O, Beszterda M and Golinski P (2016) Water stress and vegetable crops. Water Stress and Crop Plants: A Sustainable Approach, 2: 393-411. https://doi.org/10.1002/9781119054450.ch24

[79] United Nations Conference on Trade and Development UNCTAD (2014) Transfer of technology and knowledge sharing for development science, technology and innovation issues for developing countries. United Nations, Geneva, Switzerland.

[80] Asrar-ul-Haq M and Anwar S (2016) A systematic review of knowledge management and knowledge sharing: Trends, issues, and challenges. Cogent Business and Management, 3(1): 1127744. DOI: 10.1080/23311975.2015.1127744

[81] Assan N (2021) Goat-a sustainable and holistic approach in addressing triple challenges of gender inequality, climate change effects, food and nutrition insecurity in rural communities of Sub Saharan Africa. In Goat Science-Environment, Health and Economy. IntechOpen. DOI: 10.5772/intechopen.96408 Available from: https://www.intechopen.com/online-first/75448

[82] Tabari H (2020) Climate change impact on flood and extreme precipitation increases with water availability. Scientific Reports, 10(1): 1-10. https://doi.org/10.1038/s41598-020-70816-2

[83] Biasutti M (2013) Forced Sahel rainfall trends in the CMIP5 archive. Journal of Geophysical Research: Atmospheres, 118: 1613-1623. DOI:10.1002/jgrd.50206 